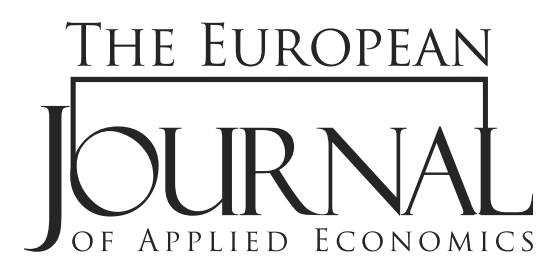

EJAE 2021, 18(1): 39 - 54

ISSN 2406-2588

UDK: 338.48-12:330.567.22(497.11)"2006/2019"

331.218.3(497.11)"2006/2019"

DOI: 10.5937/EJAE18-29551

Original paper/Originalni naučni rad

\title{
ECONOMETRIC EXAMINATION OF THE IMPACT OF INCOME ON HOUSEHOLD EXPENDITURES FOR PACKAGE HOLIDAYS IN SERBIA
}

\author{
Faculty of banking, \\ Belgrade banking academy, \\ Union University, \\ Belgrade, Serbia
}

Hasan Hanić, Milica Bugarčić*, Radojko Lukić

\begin{abstract}
:
The subject of this paper is the econometric examination of the impact of income on expenditures, i.e. on the demand for package holidays of households in Serbia. The aim of this paper is to quantify the impact of income on household expenditures for package holidays in the country and abroad on the basis of alternative functional forms of Engel curves and elasticities derived from them. The starting research hypothesis is that with the increase in household income, the share of expenditures for tourist arrangements in total household expenditures in Serbia remains approximately unchanged. As sources of data, Household Budget Surveys in Serbia were used, which were conducted every year, starting from 2006 (until 2019). Based on the different functional forms of Engel curves, the parameters of the impact of income on expenditures for package arrangements were estimated, and then income elasticities were estimated. In addition to the impact of income, the impact of qualitative characteristics of households and especially household heads on expenditures for tourist arrangements was examined. With the help of appropriate statistical tests, the basic research hypothesis was proven and the influence of socio-economic and demographic characteristics of households on the demand for package holidays was quantified.
\end{abstract}

Article info:

Received: November 24, 2020

Correction: December 28, 2020

Accepted: February 10, 2021

\section{Keywords:}

income elasticities, package holidays, Engel curve, parameter significance, dummy variable.

\section{INTRODUCTION}

In 1857, Ernest Engel formulated the regularities in the behavior of consumption depending on the changes in the total earnings (i.e. income) of households depending on expenditures, and finally formulated them in 1895 in the form of precise conclusions, which were later called Engel's laws. In brief, these laws can be formulated as follows: the percentage of food expenditures changes in inverse proportion to changes in income; the share of expenditure on clothing, footwear and housing is 
approximately constant for all income levels; with the increase in income, the share of expenditures for health, cultural needs, entertainment, etc. also grows. These laws have been empirically tested by numerous researchers in different countries and at different periods in the same countries to examine their spatial and temporal universality. The starting research hypothesis in this paper is that expenditures for tourist arrangements grow in proportion to the increase in household income, i.e. in the terminology of elasticity, the starting hypothesis is as follows: income elasticities of household expenditures in Serbia for tourist arrangements are equal to one.

\section{LITERATURE REVIEW}

Depending on whether the demand for a particular product or service is viewed in isolation from the formation of demand for other products and services or as an element of a consumer demand system in which a simultaneous demand formation process is observed that takes into account the substitution and complementarity of products and services consumption, empirical econometric research uses two fundamentally different methodological approaches to demand modeling. The first approach, known in the literature as partial modeling, is reflected in modeling the demand for a particular product or service by a regression equation, while the second approach, known in the literature as a complex approach to the study of demand, consists of modeling demand using complete systems of regression equations.

Different functional forms were used in the analysis of demand using a complex approach: WorkingLeser model, Linear Expenditure System, Additive-logarithmic model, Transcendental logarithmic model, Rotterdam model with absolute prices, Rotterdam model with relative prices, Almost Ideal Demand System, Quadratic Almost Ideal Demand System (Hanić \& Bugarčić, 2020). Some of these models allow the qualitative characteristics of consumers to be included in the regression equations of demand in addition to the variables of consumer income and prices of individual products and services, with households being most often observed as consumer units. In this respect, the most popular functional forms of complete regression equation systems are Almost Ideal Demand System (AIDS) and Quadratic Almost Ideal Demand System (QUAIDS).

Using the QUAIDS model of complete Regression Equation Systems, Coenen and Van Eekeren (2003) estimated income and price elasticities of tourism spending based on a survey of a relatively large number of Swedish households between January 1990 and October 1996. The original sample included 370604 observations, with each observation referring to one tourist trip that the surveyed household had in the observed period. In the procedure of econometric evaluation of model parameters, only those observations were taken into account that reflected the fact that tourist trips were realized by all household members in the observed period. The results obtained by these researchers reveal that household expenditures for tourist trips in relation to income are elastic (elasticity greater than one), or normally elastic (elasticity approximately equal to one) where the numerical value of income elasticities varies depending on socio-economic and demographic characteristics of the household. They showed, for example, that income elasticity is affected by the age structure of the household - for households with children aged 7 to 12 , income elasticity is 1.2 , while households with children aged between 19 and 20 have an income elasticity of 1.0.

The AIDS model of the complete systems of regression equations of demand was used, for example, by Sadeghi, Jamshidi, and Tayyebi (2005) based on a sample of 504 households which had a vacation in Hamedan Province in 2003 to estimate income and price elasticities of demand for tourist travels in the country. 
The results of empirical research of these authors have shown that expenditures for tourist trips in the country in relation to household income are approximately equal to one, i.e. that the demand for this type of tourist services is normally elastic in relation to income, and that the price elasticity of demand is less than one, that is, that the demand for domestic tourist services is inelastic in relation to the price of those services.

Although the complex approach to demand modeling has its theoretical foundation, the partial approach to demand modeling is more often used in empirical research, primarily due to a simpler way of estimating demand parameters and a more reliable statistical-analytical basis.

Alegre and Pou (2004) studied the impact of income, socio-economic and demographic characteristics of households on expenditure on tourism services in a sample of 18038 Spanish households surveyed between 1985 and 1996. Among other things, they came to the conclusion that expenditures for tourist trips are statistically significantly influenced by household income, level of education of the household head, free time of the household head, household size and number of employed household members.

Wang and Davidson (2010) made a valuable contribution in which they presented the results of empirical research on expenditure on travel arrangements presented in 27 separate studies. Almost all studies have shown that income and prices are key explanatory variables that can be used to explain variations in household expenditures for travel arrangements. A large number of studies have shown that the socio-economic and demographic characteristics of households are variables that can also explain a significant part of the total variations in household expenditures on tourism arrangements. The influence of the following variables is especially distinguished: gender and age structure of the household, household size, level of education of the household head.

Song, Eugenio-Martin and Campos-Soria (2011) conducted a survey on a sample of 16,153 households from 15 European countries surveyed in 1997. They found that the income elasticity of expenditures for tourist trips in the country is 0.377 , i.e. that expenditures are inelastic in relation to household income and that expenditures for tourist trips abroad are relatively elastic (the coefficient of income elasticity is 1,188). They also found that patterns of household behavior in this area are determined by socio-economic and demographic variables such as follows: income level, household size, age structure of the household, marital status and occupation of the household head.

Bernini and Cracolici (2015) investigated the impact of household demographic characteristics on the level of tourist travel expenditure of Italian households. Based on the sample of households surveyed during the ten-year period from 1997 to 2007, it was determined that there is a strong influence of household demographic characteristics on household expenditures for tourist trips, but also that there are significant differences in income elasticity between households whose members are of different ages.

Based on micro data obtained from surveys of consumption of Norwegian households conducted by Statistics Norway in the period from 2009 to 2012 Thrane (2016) proved the assumption that expenditures for tourist trips are strongly influenced by income, gender and age structure households.

Subanti et al. (2018) analyzed tourism expenditures in Central Java Province in Indonesia depending on household income per member, but also socio-economic and demographic factors and regional household affiliation and found that age and gender structure, household income, level of education of the household head and household members, the number of household members, the degree of urbanity of the settlement in which the household has its residence are variables that statistically significantly affect expenditures for tourist travel. 
Based on data from surveys on the consumption of Kenyan households conducted in 2015-2016 Odeny (2019) examined the impact of income and a number of socio-economic and demographic characteristics of households on expenditures for domestic tourism. The results of the empirical econometric analysis showed that the age of household members, gender of household head, marital status, employment and household size are variables that can be used to explain variations in Kenyan households' travel expenditures.

Finally, Haq, Ullah, and Sajjad (2019) analyzed the impact of socioeconomic factors on the share of recreation, culture, and travel expenditures in total expenditures of Pakistani households. They found that there is a significant positive impact of income, the level of economic development of the region to which the household belongs and the level of education and age of the household head, as well as the fact that household size negatively affects the level of expenditure on recreation and tourism. Therefore, expenditures for recreation and tourism of bigger households are lower per household member.

Theoretical, methodological and empirical aspects of the demand for tourist services were dealt with, among others, by the following authors: Cortés-Jiménez and Blake (2011), Schiff and Becken (2011), Nelson, Dickey and Smith (2011), Wu, Li and Song (2012), Baležentis et al. (2012), Konovalova and Vidishcheva (2013), Fuleky, Zhao and Bonham (2014), Gatt and Falzon (2014), Untong et al. (2014, 2015), Peng et al. (2015), Martins, Gan and Ferreira-Lopes (2017), Dogru, Mariyono (2017), Sirakaya-Turk and Crouch (2017), Khoshnevis Yazdi and Khanalizadeh (2017), Falk and Lin (2018), Fredman and Wikström (2018) and Kumar and Kumar (2020).

\section{METHODOLOGY}

Partial modeling of consumer demand is based, as it has already been stipulated above, on the formulation of a demand model in the form of a regression equation

$$
q=h\left(m, p_{1}, p_{2}, \ldots, p_{n}\right)+\varepsilon
$$

where $q$ denotes the dependent variable - demand for the observed product or service, $m$ income of the bearer of demand (individual or household) $p_{1}, p_{2}, \ldots, p_{n}$ explanatory variables - prices of products and services on which income is spent, $h\left(m, p_{1}, p_{2}, \ldots, p_{n}\right)$ systematic component of demand, i.e. that part $q$ which is formed under the influence of factors $m, p_{1}, p_{2}, \ldots, p_{n}$, that systematically affect demand, $h$ denotes the dependence of demand on factors that systematically affect demand, while $\varepsilon$ denotes a random component of the model, i.e. that component of demand that is the result of the action of many factors that randomly act in the direction of increasing or decreasing demand, where the influence of any such factor is not significant.

The first step in empirical - econometric partial modeling of demand is the choice of functional form $h$ which best represents the dependence of demand on the factor that determines it or, econometrically speaking, the choice of a particular specification of the demand model, taking into account the complexity of parameter estimation methods, their statistical properties, such as: linearity, impartiality, consistency, existentialism, efficiency, etc. (Hanic, 2018).

If it is assumed that prices are constant, as is the case when data on demand or consumption or household expenditure are collected using surveys conducted at short intervals (month, quarter or year), then the previous demand model can be written in the following form

$$
q=f(m)+\varepsilon
$$


The demand model written in the previous form, which is known in the literature as Engel's model, allows to quantify the "pure" impact of changes in income on changes in expenditures on the basis of cross-sectional data obtained through household consumption surveys (Hanić and Bugarčić, 2020). The graph of the function $q=f(m)$, where the dependent variable denotes the natural or value-expressed consumption of a given product or service, and $m$ the household income, is called the Engel curve. In the analysis of expenditures for package holidays of households in Serbia, the following functional forms are used:

Linear model: $Y=a+\beta X, E=\frac{\beta}{Y}$

Quadratic model $V=a+\beta \log X+\gamma X^{2}, E=\frac{X}{V}(\beta-2 \gamma X)$

Log-log model: $\log Y=a+\beta \log X, E=\beta$

Lin-log model: $Y=a+\beta \log X, E=\frac{\beta}{Y}$

Log-lin model: $Y=a+\beta X, E=\beta X$

Reciprocal model: $V=a+\frac{\beta}{X}, E=\frac{\beta}{a X-\beta}$

Log-reciprocal model: $Y=a-\frac{\beta}{X}, E=\frac{\beta}{X}$

For each analytical form of Engel curves, an implied mathematical expression is given that expresses the dependence of income elasticity on income level. As it can be seen from this presentation, only the log-log Engel consumption model, in which both variables are expressed in logarithmic form, implies a constant income elasticity. In all other cases, income elasticity is different at different levels of household income. To calculate the numerical value of income elasticity that approximates the elasticity of expenditure in relation to income for the entire income interval, variable $X$ is approximated by the corresponding mean value - arithmetic, geometric or harmonic mean, depending on the econometric specification of the model

In addition to the analysis of income as the main explanatory variable, the impact of other socioeconomic and demographic characteristics of the household (household size, regional household affiliation and level of education of the household head) was quantified, which are assumed to affect household expenditures for package holidays, apart from income or in interaction with income The variables such as Household size, Regional affiliation and Level of education of the household head are included in the model using dummy variables, as independent variables and as variables that interact with income, measuring changes in the initial income level and the slope of the demand curve:

$$
Y=a_{i}+\beta_{i} X+\sum_{k=1}^{K} \gamma_{i k} z_{k}+\sum_{k=1}^{K} \delta_{i k} X z_{k}+\varepsilon_{i}
$$


Since each of these qualitative (categorical) variables has four modalities, three artificial variables are defined for each of them:

1. Level of education of the head of household

$$
\begin{aligned}
& Z_{11}=\left\{\begin{array}{c}
1 \text { - if head of household has elementary education } \\
0 \text { - for all other situation }
\end{array}\right\} \\
& Z_{12}=\left\{\begin{array}{c}
1-\text { if head of household has secondary education } \\
0 \text { - for all other situation }
\end{array}\right\} \\
& Z_{13}=\left\{\begin{array}{c}
1-\text { if head of household has tertiary education } \\
0 \text { - for all other situation }
\end{array}\right\}
\end{aligned}
$$

2. Regional affiliation of the household

$$
\begin{aligned}
& Z_{21}=\left\{\begin{array}{c}
1-\text { two, three or four household members } \\
0 \text { - for all other situations }
\end{array}\right\} \\
& Z_{22}=\left\{\begin{array}{c}
1-\text { five, six or seven household members } \\
0-\text { for all other situations }
\end{array}\right\} \\
& Z_{23}=\left\{\begin{array}{c}
1 \text { - household on territory of Šumadija and Zapadna Srbija } \\
0 \text { - for all other situations }
\end{array}\right\}
\end{aligned}
$$

3. Size of household

$$
\begin{aligned}
& Z_{31}=\left\{\begin{array}{c}
1-t w o, \text { three or four household members } \\
0-\text { for all other situation }
\end{array}\right\} \\
& Z_{32}=\left\{\begin{array}{c}
1-\text { five, six or seven household members } \\
0-\text { for all other situation }
\end{array}\right\} \\
& Z_{33}=\left\{\begin{array}{c}
1-\text { fmore than seven household members } \\
0-\text { for all other situation }
\end{array}\right\}
\end{aligned}
$$

The survey has been conducted on micro data collected by the Statistical Office of the Republic of Serbia through surveys on household consumption in Serbia according to the methodology of the EU Agency for Statistics (EUROSTAT), the International Labor Organization and the United Nations, every year since 2006 .

The databases which were used contain annual data on all household expenditures, starting from consumer goods and services intended to meet daily needs, and for which households record expenditures daily in the consumption diary, to expenditures for semi-durable and durable goods and services. In addition to expenditure data, consumption surveys also contain sources of household income as well as the socio-economic characteristics of each surveyed household of each of its members. 
Products and services of personal consumption according to the Classification of Products and Services of Personal Consumption by Purpose (COICOP) are classified into 12 groups: 1) Food and non-alcoholic beverages; 2) Alcoholic beverages and tobacco; 3) Clothing and footwear; 4) Housing, water, electricity, gas and other fuels; 5) Equipment for the apartment and current maintenance; 6) Health; 7) Transport; 8) Communications; 9) Recreation and culture; 10) Education; 11) Restaurants and hotels; 12) Other personal items and other services. Expenditures for package holidays belong to the group "Recreation and Culture".

Table 1: Structure of household samples in Serbia, 2006-2019

\begin{tabular}{|c|c|c|c|c|}
\hline Year & $\begin{array}{l}\text { Number of } \\
\text { households } \\
\text { surveyed }\end{array}$ & $\begin{array}{l}\text { Number of } \\
\text { households } \\
\text { assessed }\end{array}$ & $\begin{array}{l}\text { Fraction } \\
\text { in } \%\end{array}$ & $\begin{array}{c}\text { Average } \\
\text { size of } \\
\text { households }\end{array}$ \\
\hline 2006 & 4560 & 2536714 & 0.18 & 3.15 \\
\hline 2007 & 4608 & 2536714 & 0.18 & 2.95 \\
\hline 2008 & 4621 & 2536714 & 0.18 & 3.04 \\
\hline 2009 & 4592 & 2536714 & 0.18 & 3.00 \\
\hline 2010 & 4585 & 2536714 & 0.18 & 2.94 \\
\hline 2011 & 4592 & 2536714 & 0.18 & 2.89 \\
\hline 2012 & 4546 & 2536714 & 0.18 & 2.88 \\
\hline 2013 & 4517 & 2465799 & 0.18 & 2.88 \\
\hline 2014 & 6071 & 2466316 & 0.25 & 2.86 \\
\hline 2015 & 6531 & 2466316 & 0.26 & 2.81 \\
\hline 2016 & 6457 & 2466316 & 0.26 & 2.74 \\
\hline 2017 & 6403 & 2466316 & 0.26 & 2.70 \\
\hline 2018 & 6296 & 2466316 & 0.26 & 2.66 \\
\hline 2019 & 6354 & 2466316 & 0.26 & 2.68 \\
\hline Average & 5259 & 2501478 & 0.21 & 2.85 \\
\hline
\end{tabular}

Source: Statistical Office of the Republic of Serbia

In the research, 14 partial databases were used, and each database includes data collected by household surveys for a certain year of the observed period (2006-2019). The average annual number of surveyed households in Serbia is 5,259, with the number of respondents increasing every year, as shown by Table 1: the survey sample in 2006 and in 2019 covered 4,560, 6,354 households respectively. 


\section{RESULTS AND DISCUSSION}

The number of households that have expenditures for package holidays is relatively small. In 2006, only 165 out of a total of 4560 households or 3.6\% had expenditures for package holidays, while in 2019 the share of households with expenditures on package holidays increased about 2.5 times, so that it amounted to $8.7 \%$.

Figure 1: Structure of households that had expenditures for package holidays in 2019 according to the amount of income, household size, regional affiliation and level of education of the household head
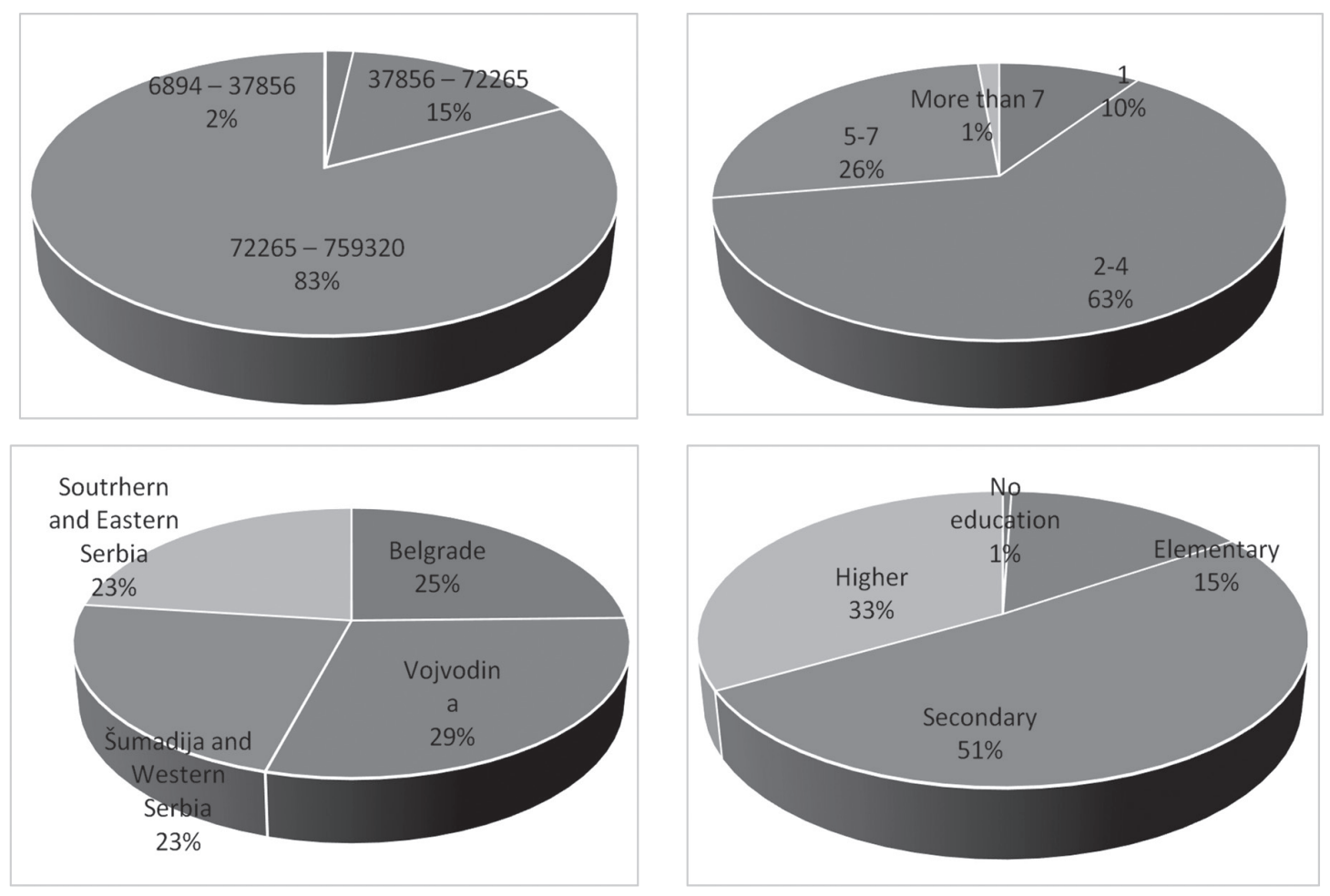

The average monthly expenditure of households in 2019 amounted to 1371 dinars, or it was eight times higher than in 2006, when it amounted to 170 dinars. The average amount of expenditures of households that spent on package holidays was 15696 dinars in 2019, compared to 2006 when it amounted to 4709 dinars.

Table 2 indicates that only 18 households in Serbia in 2019 whose income ranged from 6894 to 37856 dinars spent on package holidays. There are 86 such households from the income range from 37856 to 72265 dinars, while in the income interval from 72265 to 759320 dinars there are 3776 households that spent on package holidays. In 2019, the share of expenditures for package holidays in all income groups was approximately $12 \%$, which implies a unit elasticity of expenditures in relation to household income. 
Table 2: Household expenditures for package holidays in 2006 and 2019 according to income

\begin{tabular}{|c|c|c|c|c|c|c|c|c|}
\hline \multirow[b]{2}{*}{ Year } & \multirow[b]{2}{*}{ Income in RSD } & \multicolumn{3}{|c|}{ All households } & \multicolumn{4}{|c|}{ Households which had expenditures } \\
\hline & & $\begin{array}{c}\text { Number } \\
\text { of house- } \\
\text { holds }\end{array}$ & $\begin{array}{l}\text { Average } \\
\text { income }\end{array}$ & $\begin{array}{l}\text { Expe- } \\
\text { nditures in } \\
\text { RSD }\end{array}$ & $\begin{array}{c}\text { House- } \\
\text { hold } \\
\text { percentage }\end{array}$ & $\begin{array}{l}\text { Expe- } \\
\text { nditures in } \\
\text { RSD }\end{array}$ & $\begin{array}{l}\text { Average } \\
\text { income }\end{array}$ & $\begin{array}{l}\text { Share of } \\
\text { expendi- } \\
\text { tures }\end{array}$ \\
\hline \multirow{4}{*}{2006} & $1984-285301$ & 4560 & 33339 & 170 & 3.6 & 4709 & 63513 & 0.07 \\
\hline & $1984-21164$ & 1519 & 13689 & 4 & 0.26 & 1575 & 18947 & 0.08 \\
\hline & $21164-36889$ & 1519 & 28775 & 27 & 1.38 & 1948 & 29699 & 0.07 \\
\hline & $36889-285301$ & 1521 & 57536 & 480 & 9.2 & 5213 & 69858 & 0.07 \\
\hline \multirow{4}{*}{2019} & $6894-759320$ & 6354 & 66049 & 1371 & 8.7 & 15696 & 129611 & 0.12 \\
\hline & $6894-37856$ & 2118 & 25640 & 18 & 0.5 & 3826 & 32352 & 0.12 \\
\hline & $37856-72265$ & 2102 & 53780 & 293 & 4.1 & 7163 & 59461 & 0.12 \\
\hline & $72265-759320$ & 2134 & 118240 & 3776 & 21.5 & 17554 & 144873 & 0.12 \\
\hline
\end{tabular}

Table 3 shows the estimated values of the parameters of the used functional forms of Engel curves, together with the relevant statistical indicators $\mathrm{p}$-value, value of F-statistics, coefficient of determination and the value of Akaike information criterion, for 2006 and 2019.

Based on the value of the coefficient of determination, it can be concluded that in 2006 the double logarithmic form with constant elasticity best described the dependence of expenditures for package holidays on household income, while in 2019 the quadratic functional form represented the best example of the studied dependence. However, if the value of the Akaike information criterion is taken into account, then the conclusion can be drawn that Engel's curve with constant elasticity best approximates the dependence of household expenditures for tourist arrangements on the level of household income in 2006 and 2019.

Table 3: Estimated parameters of Engel curves in 2006 and 2019

\begin{tabular}{|c|c|c|c|}
\hline Model & Year & 2006 & 2019 \\
\hline \multirow{6}{*}{ Linear } & Equation & $Y_{i}=-432.509+0.018 X_{i}$ & $Y_{i}=-4591.456+0.071 X_{i}$ \\
\hline & $\mathrm{p}$-value & 0.000 & 0.000 \\
\hline & $\mathrm{F}$ & 421.198 & 309.956 \\
\hline & Prob $>$ F & 0.0000 & 0.0000 \\
\hline & $\mathrm{R}^{2}$ & 0.084 & 0.127 \\
\hline & AIC & 78892.704 & 45055.320 \\
\hline \multirow{6}{*}{ Log-log } & Equation & $\log \mathrm{Y}_{\mathrm{i}}=-4.562+1.131 \log \mathrm{X}_{\mathrm{i}}$ & $\log Y_{i}=-3.599+1.094 \log X_{i}$ \\
\hline & $\mathrm{p}$-value & 0.000 & 0.000 \\
\hline & $\mathrm{F}$ & 41.493 & 69.999 \\
\hline & Prob $>F$ & 0.0000 & 0.0000 \\
\hline & $\mathrm{R}^{2}$ & 0.198 & 0.131 \\
\hline & AIC & 498.540 & 1319.004 \\
\hline \multirow{6}{*}{ Log-lin } & Equation & $\log Y_{i}=6.845+0.000 X_{i}$ & $\log Y_{i}=8.403+0.000 X_{i}$ \\
\hline & $\mathrm{p}$-value & 0.000 & 0.000 \\
\hline & $\mathrm{F}$ & 42.003 & 61.917 \\
\hline & Prob $>F$ & 0.0000 & 0.0000 \\
\hline & $\mathrm{R}^{2}$ & 0.200 & 0.117 \\
\hline & AIC & 498.129 & 1326.097 \\
\hline
\end{tabular}




\begin{tabular}{|c|c|c|c|}
\hline Model & Year & 2006 & 2019 \\
\hline \multirow{6}{*}{ Lin-log } & Equation & $Y_{i}=-3811.560+390.335 \log X_{i}$ & $Y_{i}=-1.255 e+05+11129.319 \log X_{i}$ \\
\hline & $\mathrm{p}$-value & 0.000 & 0.000 \\
\hline & $\mathrm{F}$ & 156.461 & 338.873 \\
\hline & Prob $>$ F & 0.0000 & 0.0000 \\
\hline & $\mathrm{R}^{2}$ & 0.033 & 0.137 \\
\hline & AIC & 79141.836 & 45030.198 \\
\hline \multirow{6}{*}{ Quadratic } & Equation & $Y_{i}=152.803-0.011 X_{i}-0.000 X_{i}^{2}$ & $Y_{i}=-9454.586+0.134 X_{i}-0.000 X_{i}^{2}$ \\
\hline & p-value & 0.000 & 0.000 \\
\hline & $\mathrm{F}$ & 390.871 & 182.972 \\
\hline & Prob $>$ F & 0.0000 & 0.0000 \\
\hline & $\mathrm{R}^{2}$ & 0.146 & 0.146 \\
\hline & AIC & 78575.776 & 45008.798 \\
\hline \multirow{6}{*}{ Recipro-cal } & Equation & $\mathrm{Y}_{\mathrm{i}}=319.884-\frac{3.146 \mathrm{e}+06}{\mathrm{X}_{\mathrm{i}}}$ & $\mathrm{Y}_{\mathrm{i}}=16063.307-\frac{1.300 \mathrm{e}+09}{\mathrm{X}_{\mathrm{i}}}$ \\
\hline & $\mathrm{p}$-value & 0.000 & 0.000 \\
\hline & $\mathrm{F}$ & 38.134 & 297.417 \\
\hline & Prob $>$ F & 0.0000 & 0.0000 \\
\hline & $\mathrm{R}^{2}$ & 0.008 & 0.122 \\
\hline & AIC & 79257.747 & 45066.306 \\
\hline \multirow{6}{*}{$\begin{array}{l}\text { Log- } \\
\text { reciprocal }\end{array}$} & Equation & $\log Y_{i}=8.789+\frac{49412.567}{X_{i}}$ & $\log \mathrm{Y}_{\mathrm{i}}=10.508+\frac{1.500 \mathrm{e}+05}{\mathrm{X}_{\mathrm{i}}}$ \\
\hline & $\mathrm{p}$-value & 0.000 & 0.000 \\
\hline & $\mathrm{F}$ & 30.600 & 69.620 \\
\hline & Prob $>$ F & 0.0000 & 0.0000 \\
\hline & $\mathrm{R}^{2}$ & 0.153 & 0.130 \\
\hline & AIC & 507.573 & 1319.334 \\
\hline
\end{tabular}

Based on the estimated parameters of the selected econometric specifications, the income elasticities of expenditures for package holidays in Serbia for each specification and for each year of the analyzed period (2006-2019) were evaluated.

Based on the numerical value of income elasticity estimated using the double-logarithmic form, as the dominant best representative of the studied dependence, it can be seen that in the observed period there was a decrease in elasticity from 1.13 to 1.02. Except for the years 2014 and 2017, when the elasticities estimated on the basis of the log-log functional form were 0.77 and 0.93 , respectively, the income elasticities of expenditures in all other years of the analyzed period were higher than one, which is in line with the basic postulate of economy of tourism and tourist demand theory. However, based on Wald's F-test, it was found that the yield elasticity did not differ significantly from one, thus confirming the basic research hypothesis. When interpreting this result, it should be taken into consideration that when calculating the parameters of log-log functions, households where no expenditures for package holidays were registered are excluded from the analysis. 
Such conclusions were reached by Sadeghi, Jamshidi, and Tayyebi (2005) who examined the impact of income on Iranian household expenditures on travel arrangements, and Song, Eugenio-Martin, and Campos-Soria (2011) who conducted a survey on a sample of households from 15 European countries.

If, on the other hand, the results obtained using linear, linear-logarithmic and logarithmic-inverse functions are taken into account, then it can be reliably concluded that the elasticity of expenditures for package holiday arrangements is significantly higher than one. In all years of the observed period, the income elasticities estimated on the basis of the linear and lin-log functions are significantly higher than one. The average values of elasticity in the observed period estimated on the basis of these functions are 2.9 and 2.2, respectively. Income elasticities estimated on the basis of the logarithmic-inverse function in all years of the observed period except in 2014, are higher than one. Their average value is 1.3 . This result is in line with the postulate of the tourist demand theory, according to which the share of expenditures for package holiday arrangements in the income of consumers increases with the increase of income.

Table 4: Income elasticities of expenditures for package holidays in Serbia, estimated on the basis of different forms of Engel curves, 2006-2019.

\begin{tabular}{ccccccccc}
\hline Year & Linear & Log-Log & Log-Lin & Lin-Log & Quadratic & Reciprocal & $\begin{array}{c}\text { Log- } \\
\text { reciprocal }\end{array}$ \\
\hline 2006 & 3.52 & 1.13 & 0.00 & 2.29 & -2.15 & 0.55 & 1.48 \\
\hline 2007 & 2.24 & 1.03 & 0.00 & 1.79 & 1.68 & 0.46 & 1.25 \\
\hline 2008 & 3.14 & 1.26 & 0.00 & 2.14 & -2.39 & 0.66 & 1.58 \\
\hline 2009 & 2.46 & 1.02 & 0.00 & 1.99 & 1.80 & 0.69 & 1.11 \\
\hline 2010 & 2.85 & 1.18 & 0.00 & 2.30 & 1.28 & 0.82 & 1.85 \\
\hline 2011 & 3.54 & 1.14 & 0.00 & 2.60 & -2.25 & 0.90 & 1.24 \\
\hline 2012 & 3.08 & 1.12 & 0.00 & 2.42 & 3.08 & 0.69 & 1.27 \\
\hline 2013 & 3.72 & 1.04 & 0.00 & 2.49 & -4.29 & 0.73 & 1.11 \\
\hline 2014 & 2.93 & 0.77 & 0.00 & 2.16 & 0.00 & 0.76 & 0.85 \\
\hline 2015 & 3.15 & 1.24 & 0.00 & 2.19 & -1.58 & 0.69 & 1.27 \\
\hline 2016 & 3.23 & 1.15 & 0.00 & 2.18 & -1.50 & 0.64 & 1.06 \\
\hline 2017 & 2.47 & 0.93 & 0.00 & 2.03 & 1.94 & 0.75 & 1.11 \\
\hline 2018 & 2.25 & 1.08 & 0.00 & 2.06 & 2.51 & 0.78 & 1.29 \\
\hline 2019 & 2.51 & 1.02 & 0.00 & 2.14 & 2.51 & 0.82 & 1.32 \\
\hline
\end{tabular}

In addition to the impact of income on expenditures for package arrangements, the impact of socioeconomic and demographic characteristics of households (regional affiliation and household size, level of education of the household head) was also examined. Based on the value of the F-test used to test the significance of differences in the average level of household expenditure belonging to different regions, it was found that there is a statistically significant difference $(F(3,6346)=18.99$, Prob $>F=0.0000)$ in average household expenditure for package arrangements of households belonging to Belgrade, Vojvodina, Šmadija and Western Serbia and Southern and Eastern Serbia. Using the F-test, the hypothesis was tested on the significance of the impact of the level of education of the household head (with modalities: no education, elementary, secondary and higher education) on expenditures for package holidays in Serbia in 2019 and found that the level of education of the household head significantly determines differences in household expenditures for package holidays $(\mathrm{F}(3.6346)=14.85$; Prob $>\mathrm{F}=0.0000)$. 
In the same way, the assumption that household size represents a statistically significant source of variation in household expenditures for package holidays has been proven - in 2019 where $\mathrm{F}(3,346)=13.21$; and Prob $>\mathrm{F}=0.0000$.

Table 5. provides basic indicators of the impact of socio-economic and demographic characteristics of households on expenditures for package holidays in Serbia in 2019.

In accordance with the result of the F-test, which showed that the level of education of the household head affects expenditures on package holidays, significant differences in income elasticities were obtained as indicators of the intensity of the impact of income on expenditures for different households with different levels of education. Thus, for example, the income elasticity in 2019 of households in which the head has higher education was 0.66 , while for households with the lowest level of education of the household head, the income elasticity was 1.50 . Therefore it can be concluded that in the first category of households, package holidays have the status of a necessary good, and in the categories with a lower level of education, they enjoy the status of a luxury good. This result corresponds to the results obtained by researchers Alegre and Pou (2004) in Spain, Subanti et al. (2018) in Central Java Province in Indonesia, and Haq, Ullah and Sajjad (2019) in Pakistan.

Table 5: Characteristic values of the studied socio-economic and demographic segments of households in Serbia, 2019.

\begin{tabular}{|c|c|c|c|c|c|}
\hline Variable & Modality & $\begin{array}{c}\text { Share of } \\
\text { households } \\
\text { which have } \\
\text { expenditures } \\
\text { on package } \\
\text { holidays }\end{array}$ & $\begin{array}{c}\text { Average } \\
\text { expenditures }\end{array}$ & $\begin{array}{l}\text { Average i } \\
\text { ncome }\end{array}$ & $\begin{array}{c}\text { Income } \\
\text { elasticities } \\
(\log -\log )\end{array}$ \\
\hline \multirow{4}{*}{$\begin{array}{l}\text { Level of } \\
\text { education of } \\
\text { the head of the } \\
\text { household }\end{array}$} & No education & 0.02 & 375 & 35503 & 1.50 \\
\hline & Elementary & 0.04 & 573 & 49938 & 1.11 \\
\hline & Secondary & 0.09 & 1341 & 68734 & 1.10 \\
\hline & Higher & 0.16 & 2927 & 90017 & 0.66 \\
\hline \multirow{4}{*}{$\begin{array}{c}\text { Number of } \\
\text { household } \\
\text { members }\end{array}$} & 1 & 0.03 & 458 & 32244 & 1.32 \\
\hline & $2-4$ & 0.09 & 1480 & 70819 & 1.08 \\
\hline & $5-7$ & 0.19 & 2817 & 114039 & 1.64 \\
\hline & $>7$ & 0.15 & 2166 & 122404 & 2.53 \\
\hline \multirow{4}{*}{ Region } & Belgrade & 0.11 & 1802 & 75660 & 1.05 \\
\hline & Vojvodina & 0.09 & 1183 & 62193 & 0.75 \\
\hline & $\begin{array}{l}\text { Šumadija and } \\
\text { Western Serbia }\end{array}$ & 0.07 & 1267 & 65479 & 1.00 \\
\hline & $\begin{array}{l}\text { Southern and } \\
\text { Eastern Serbia }\end{array}$ & 0.08 & 1361 & 63402 & 1.26 \\
\hline \multirow{3}{*}{ Income } & $6894-37856^{\star}$ & 0.00 & 3826 & 32352 & -0.04 \\
\hline & $37856-72265^{\star}$ & 0.04 & 7163 & 59461 & -0.46 \\
\hline & $72265-759320$ & 0.22 & 17554 & 144873 & 1.09 \\
\hline
\end{tabular}

*Note: insufficient number of observations for reliable conclusions 
The estimated income elasticities show that the size and regional affiliation of the household are variables that also determine to a statistically significant extent the variations in expenditures for package holidays depending on the amount of income. In households with a small number of members, income elasticities are significantly lower compared to the income elasticities of households with a larger number of members. Significance of the household size variable was also confirmed in studies by Alegre and Pou (2004) in Spain, Song, Eugenio-Martin and Campos-Soria (2011) in 15 European countries, Subanti et al. (2018) in Central Java Province in Indonesia, Odeny (2019) in Kenya, Haq, Ullah and Sajjad (2019) in Pakistan. The significance of the impact of regional household affiliation on the dependence of expenditures on package holidays on income has been confirmed by other researchers, including Subanti et al. (2018) in Central Java Province in Indonesia, and Haq, Ullah and Sajjad (2019) in Pakistan.

\section{CONCLUSIONS}

Summarizing the results, the following conclusion can be drawn: first, in 2006 only $3.6 \%$ of surveyed households had expenditures for package holidays, while in 2019 the share of households with expenditures for package holidays in the total number of households reached $8.7 \%$, which confirms the well-known view that the level of economic development of the country and the real disposable income, in addition to free time, are key determinants of tourist demand; second, the log-log Engel curve is a functional form that best represents the dependence of expenditures for tourist arrangements on the level of household income in Serbia; third, income levels, size and regional affiliation of the household, and the level of education of the household head are explanatory variables that explain the variations in household expenditures in Serbia to a statistically significant extent; fourth, the average value of income elasticity of expenditures for tourist arrangements based on log-log Engel's functions forthe analyzed period (2006-2019) is not significantly higher than one. When interpreting this result, the limitation should be taken into consideration that when calculating the log-log parameters of the function, parameters for the households which in certain years of the analyzed period did not have expenditures for tourist arrangements were omitted; fifth, on the basis of linear and linear-logarithmic function, whose parameters are estimated on the basis of overall observations, i.e. based on complete samples, the resultsobtained show that income elasticities are significantly higher than one, which is in line with Engel's third law, which postulates that with the increase in income, the share of expenditures for package holiday arrangements increases; sixth, over time income elasticities tend to fall which corresponds to the fact that with the increase in income, which occurs over time, income elasticity decreases. 


\section{REFERENCES}

Alegre, J., \& Pou, L. (2004). Micro-economic determinants of the probability of tourism consumption. Tourism Economics, 10(2), 125-144. https://doi.org/10.5367/000000004323142452

Baležentis, T., Kriščiukaitienè, I., Baležentis, A., \& Garland, R. (2012). Rural tourism development in Lithuania (20032010) - A quantitative analysis. Tourism Management Perspectives, 2-3, 1-6. https://doi.org/10.1016/j. tmp.2012.01.001

Bernini, C., \& Cracolici, M. F. (2015). Demographic change, tourism expenditure and life cycle behaviour. Tourism Management, 47, 191-205. https://doi.org/10.1016/j.tourman.2014.09.016

Bugarčić, M. (2019). Istraživanje uticaja dohotka na tražnju za potrošnim dobrima - Teorijsko-metodološke osnove i empirijska primena [Research of the influence of income on the demand for consumer goods - Theoretical and methodological bases and empirical application]. Doctoral dissertation, Union University: Belgrade banking academy, Belgrade. Retrieved from: https:/nardus.mpn.gov.rs/bitstream/handle/123456789/11885/ DISERTACIJA-MB-FIN-SA-IZJAVOM.pdf?sequence=7\&isAllowed=y

Coenen, M., \& Van Eekeren, L. (2003). A study of the demand for domestic tourism by Swedish households using a two-staged budgeting model. Scandinavian Journal of Hospitality and Tourism, 3(2), 114-133. https:// doi.org/10.1080/15022250310002421

Cortés-Jiménez, I., \& Blake, A. (2011). Tourism Demand Modeling by Purpose of Visit and Nationality. Journal of Travel Research, 50(4), 408-416. https://doi.org/10.1177/0047287510363615

Dogru, T., Sirakaya-Turk, E., \& Crouch, G. I. (2017). Remodeling international tourism demand: Old theory and new evidence. Tourism management, 60, 47-55. https://doi.org/10.1016/j.tourman.2016.11.010

Eugenio-Martin, J. L., \& Campos-Soria, J. A. (2011). Income and the substitution pattern between domestic and international tourism demand. Applied Economics, 43(20), 2519-2531.https://doi.org/10.1080/00036840903299698

Gatt, W., \& Falzon, J. (2014). British tourism demand elasticities in Mediterranean countries. Applied Economics, 46(29), 3548-3561. https://doi.org/10.1080/00036846.2014.934432

Falk, M., \& Lin, X. (2018). Income elasticity of overnight stays over seven decades. Tourism Economics, 24(8), 1015-1028. https://doi.org/10.1177/1354816618803781

Fredman, P., \& Wikström, D. (2018). Income elasticity of demand for tourism at Fulufället National Park. Tourism Economics, 24(1), 51-63. https://doi.org/10.1177/1354816617724012

Fuleky, P., Zhao, Q., \& Bonham, C. S. (2014). Estimating demand elasticities in non-stationary panels: the case of Hawaii tourism. Annals of Tourism Research, 44, 131-142. https://doi.org/10.1016/j.annals.2013.09.006

Hanić, H., \& Bugarčić M. (2020). Econometric Analysis of the Impact of Income on Household Insurance Expenditure Based on Consumption Surveys in Serbia. In Kočović, J. (Eds.), Insurance Market after Covid-19 (pp. 207-224). Belgrade: Faculty of economics.

Hanić, H. (2018). Repetitorijum osnovnih matematičko-statističkih pojmova. Beograd: Beogradska bankarska akademija.

Haq, Z. U., Ullah, Z., \& Sajjad. (2019). Households' participation in and expenditure on recreation and tourism in Pakistan. Asia Pacific Journal of Tourism Research, 24(3), 206-218. https://doi.org/10.1080/10941665 .2018.1557227

Konovalova, A. A., \& Vidishcheva, E. V. (2013). Elasticity of demand in tourism and hospitality. European Journal of Economic Studies, (2), 84-89.

Khoshnevis Yazdi, S., \& Khanalizadeh, B. (2017). Tourism demand: A panel data approach. Current Issues in Tourism, 20(8), 787-800. https://doi.org/10.1080/13683500.2016.1170772

Kumar, N., \& Kumar, R. R. (2020). Relationship between ICT and international tourism demand: A study of major tourist destinations. Tourism Economics, 26(6), 908-925. https://doi.org/10.1177/1354816619858004

Mariyono, J. (2017). Determinants of demand for foreign tourism in Indonesia. Jurnal Ekonomi Pembangunan: Kajian Masalah Ekonomi dan Pembangunan, 18(1), 82-92. https://doi.org/10.23917/jep.v18i1.2042 
Martins, L. F., Gan, Y., \& Ferreira-Lopes, A. (2017). An empirical analysis of the influence of macroeconomic determinants on World tourism demand. Tourism Management, 61, 248-260. https://doi.org/10.1016/j. tourman.2017.01.008

Nelson, L. A., Dickey, D. A., \& Smith, J. M. (2011). Estimating time series and cross section tourism demand models: Mainland United States to Hawaii data. Tourism Management, 32(1), 28-38. https://doi.org/10.1016/j. tourman.2009.10.005

Odeny, B. (2019). Determinants of Domestic Tourism Expenditure in Kenya. Doctoral dissertation, University of Nairobi, Nairobi.

Peng, B., Song, H., Crouch, G. I., \& Witt, S. F. (2015). A meta-analysis of international tourism demand elasticities. Journal of Travel Research, 54(5), 611-633. https://doi.org/10.1177/0047287514528283

Sadeghi, J. M., Jamshidi, M., \& Tayyebi, S. K. (2005). Expenditure and Price Elasticity of Demand for Household Domestic Tourism in Iran: A Cross-Sectional Analysis. In Economic Research Forum Selected Papers from The $11^{\text {th }}$ Annual Conference (pp. 259-351). Cairo, Egypt.

Schiff, A., \& Becken, S. (2011). Demand elasticity estimates for New Zealand tourism. Tourism Management, 32(3), 564-575. https://doi.org/10.1016/j.tourman.2010.05.004

Subanti, S., Hakim, A. R., Handajani, S. S., \& Hakim, I. M. (2018). The determinant of household tourism expenditure in Central Java Province, Indonesia. Journal of Physics: Conference Series, 983(1), 012073. https://doi. org/10.1088/1742-6596/983/1/012073

Thrane, C. (2016). The determinants of Norwegians' summer tourism expenditure: foreign and domestic trips. Tourism Economics, 22(1), 31-46. https://doi.org/10.5367/te.2014.0417

Untong, A., Ramos, V., Kaosa-Ard, M., \& Rey-Maquieira, J. (2015). Tourism demand analysis of Chinese arrivals in Thailand. Tourism Economics, 21(6), 1221-1234. https://doi.org/10.5367/te.2015.0520

Untong, A., Ramos, V., Kaosa-Ard, M., \& Rey-Maquieira, J. (2014). Thailand's long-run tourism demand elasticities. Tourism Economics, 20(3), 595-610. https://doi.org/10.5367/te.2013.0280

Wang, Y. \& Davidson, M. C. (2010). A review of micro-analyses of tourist expenditure. Current issues in Tourism, 13(6), 507-524. https://doi.org/10.1080/13683500903406359

Wu, D. C., Li, G., \& Song, H. (2012). Economic analysis of tourism consumption dynamics: A time-varying parameter demand system approach. Annals of Tourism Research, 39(2), 667-685. https://doi.org/10.1016/j.annals.2011.09.003

Zavod za statistiku Republike Srbije. (2009). Anketa o potrošnji domaćinstava Zavoda za statistiku Republike Srbije. Beograd: Zavod za statistiku Republike Srbije.

Zavod za statistiku Republike Srbije. (2013). Anketa o potrošnji domaćinstava Zavoda za statistiku Republike Srbije. Beograd: Zavod za statistiku Republike Srbije.

Zavod za statistiku Republike Srbije. (2017). Anketa o potrošnji domaćinstava Zavoda za statistiku Republike Srbije. Beograd: Zavod za statistiku Republike Srbije.

Zavod za statistiku Republike Srbije. (2019). Anketa o potrošnji domaćinstava Zavoda za statistiku Republike Srbije. Beograd: Zavod za statistiku Republike Srbije. 


\section{EKONOMETRIJSKO ISPITIVANJE UTICAJA PRIHODA NA RASHODE DOMAĆINSTVA}

\section{Rezime:}

Predmet ovog rada je ekonometrijsko ispitivanje uticaja prihoda na rashode, odnosno, na potražnju za paket aranžmanima domaćinstava u Srbiji. Cilj ovog rada je da kvantifikuje uticaj prihoda na troškove domaćinstva za paket aranžmane u zemlji i inostranstvu na osnovu alternativnih funkcionalnih oblika Engelovih krivih i iz njih izvedenih elasticiteta. Početna hipoteza istraživanja je da sa povećanjem prihoda domaćinstva udeo izdataka za turističke aranžmane u ukupnim izdacima domaćinstava u Srbiji ostaje približno nepromenjen. Kao izvori podataka korišćene su Ankete o potrošnji domaćinstava u Srbiji, koje su se sprovodile svake godine, počev od 2006. (do 2019). Na osnovu različitih funkcionalnih oblika Engelovih krivih, procenjeni su parametri uticaja prihoda na troškove za paket aranžmane, a zatim su procenjene i elastičnosti dohotka. Pored uticaja prihoda, ispitivan je i uticaj kvalitativnih karakteristika domaćinstava, a posebno nosilaca domaćinstava na izdatke za turističke aranžmane. Uz pomoć odgovarajućih statističkih testova dokazana je osnovna hipoteza istraživanja i kvantifikovan je uticaj socioekonomskih i demografskih karakteristika domaćinstava na potražnju za paket aranžmanima.

\section{Ključne reči:}

elastičnost prihoda, paket aranžman, Engelova kriva, značaj parametra, veštačka varijabla. 